\title{
Why a right to life rules out infanticide: A final reply to Räsänen
}

\begin{abstract}
Joona Räsänen has argued that pro-life arguments against the permissibility of infanticide are not persuasive, and fail to show it to be immoral. We responded to Räsänen's arguments, concluding that his critique of pro-life arguments was misplaced. Räsänen has recently replied in 'Why pro-life arguments still are not convincing: a reply to my critics', providing some additional arguments as to why he does not find pro-life arguments against infanticide convincing. Here, we respond briefly to Räsänen's critique of the substance view, and also to his most important claim: that possession of a right to life by an infant does not rule out the permissibility of infanticide. We demonstrate that this claim has little support, and conclude that Räsänen has not refuted pro-life arguments against infanticide.
\end{abstract}

\section{Keywords}

Abortion, infanticide, substance view, right to life, animalism

\section{Introduction}

Joona Räsänen has $\operatorname{argued}^{1}$ that pro-life arguments against the permissibility of infanticide are not persuasive and fail to show it to be immoral. He was primarily criticising Christopher Kaczor's examination of Alberto Giubilini and Francesca Minerva's well-known article on

\footnotetext{
${ }^{1}$ Räsänen, J. (2016). Pro-life arguments against infanticide and why they are not convincing. Bioethics, 30, 656-662.
} 
infanticide, or what they call 'after-birth abortion'. Giubilini and Minerva controversially claimed that 'killing a newborn could be ethically permissible in all the circumstances where abortion would be'2, and Kaczor addresses their reasoning in some detail in his book The Ethics of Abortion ${ }^{3}$.

We responded to Räsänen's arguments ${ }^{4}$, as did Kaczor ${ }^{5}$, and we both concluded that his critique of pro-life arguments was misplaced. Räsänen has recently replied to both responses in 'Why pro-life arguments still are not convincing: a reply to my critics' ${ }^{6}$, providing some additional reasons as to why he does not find pro-life arguments against infanticide persuasive. He continues his critique of the substance view of persons and restates his primary claim: that 'pro-life arguments are mistaken and therefore cannot show infanticide (or abortion for that matter) to be morally impermissible'7. We respond to this claim, focusing on the most pertinent of Räsänen's arguments: that the possession of a right to life by an infant does not rule out the permissibility of infanticide.

\section{Substance view}

Much of Räsänen's critique of the pro-life position against infanticide is predicated on what is known as the substance view of persons. The substance view claims human beings are

\footnotetext{
${ }^{2}$ Giubilini, A., \& Minerva, F. (2013). After-birth abortion: Why should the baby live? Journal of Medical Ethics, 39, 261-263.

${ }^{3}$ Kaczor, C. (2015). The ethics of abortion (2nd ed.). New York, NY: Routledge.

${ }^{4}$ Rodger, D., Blackshaw, B.P. \& Wilcox, C. (2018). Why arguments against infanticide remain convincing: A reply to Räsänen. Bioethics, 32, 215-219.

${ }^{5}$ Kaczor, C. (2018). A dubious defense of 'after-birth abortion': A reply to Räsänen. Bioethics, 32, $132-137$.

${ }^{6}$ Räsänen, J. (2018). Why pro-life arguments still are not convincing: a reply to my critics. Bioethics, 32(9), $628-633$.

7 Ibid: 628 .
} 
individual substances ${ }^{8}$ that are rational moral agents by nature, and it entails that we are equally valuable at every stage of our development. It is commonly invoked in defence of the pro-life position, and we have defended the substance view in our exchange with Räsänen. He continues his criticisms of the substance view in his most recent reply. We have chosen not to respond to these here, as they have been widely discussed and numerous replies already exist ${ }^{910}$.

Instead, we make a broader point that Räsänen briefly acknowledges but does not pursue: that the substance view is not the only view that can ground a pro-life stance. One actively discussed (but related) alternative is animalism, the view that we are each numerically identical with an animal ${ }^{1112}$. One of the strongest pro-life arguments, Don Marquis' 'future-like-ours' argument, is compatible with animalism. Other options include reliance on a religious or secular sanctity-of-life principle; Rosalind Hursthouse has defended a pro-life view from a virtue ethics perspective ${ }^{13}$. Indeed, the only requirement for grounding a pro-life position on infanticide is that human beings possess a right to life from conception (or even some time after conception, even from birth). This is problematic for Räsänen's main claim: that pro-life arguments are mistaken and therefore cannot show infanticide morally impermissible. His critique of the substance view at best only undermines pro-life arguments against infanticide that are predicated on the substance view of persons. To substantiate such

\footnotetext{
${ }^{8}$ Substances in the Aristotelian sense - individual entities that survive changes in their accidental properties.

${ }^{9}$ Friberg-Fernros, H. (2018). Hit but not down. The substance view in light of the criticism of Lovering and Simkulet. Bioethics 32 (6):388-394.

${ }^{10}$ Blackshaw, B. P., \& Rodger, D. (2019). The Problem of Spontaneous Abortion: Is the Pro-Life Position Morally Monstrous? The New Bioethics, 1-18. DOI: 10.1080/20502877.2019.1602376

${ }^{11}$ George, R., \& Tollefsen, C. (2011). Embryo: A defense of human life. 2nd ed. New York, NY: Doubleday

12 Olson, ET. (1997). Was I Ever a Fetus? Philosophy and Phenomenological Research, 57(1): 95-110.

${ }^{13}$ Hursthouse, R. (1991). Virtue Theory and Abortion. Philosophy \& Public Affairs 20(3):223-246.
} 
a claim requires refuting these alternative views, or making a more general argument against the pro-life argument for the impermissibility of infanticide.

\section{Infanticide and the right to life}

To his credit, Räsänen does attempt to make a broader argument, based on our assertion that infanticide can only be justified by denying the infant a right to life, and because the infant does possess a right to life, infanticide is indeed immoral. He claims, however, that even if the right to life is granted, there may be other reasons strong enough to justify infanticide. For example, Räsänen suggests that parents may have a right to their genetic privacy, and 'having the newborn infant in the world that carries the genetic material of the genetic parents violates their right to genetic privacy ${ }^{14}$. He considers that violating this right to privacy may be sufficient to override an infant's right to life. Räsänen does not develop this argument here, but has made a similar argument in the context of ectogenesis, although in that case assuming the foetus possesses only partial moral status ${ }^{15}$. We responded ${ }^{16}$, concluding that he fails to establish a right to the death of the foetus. It is obviously a far more difficult task to argue for the death of an infant which has a right to life.

Räsänen claims his intention with the genetic privacy argument is to demonstrate that an argument for the permissibility of infanticide concordant with the infant's right to life is possible. This is not persuasive - an unsubstantiated argument for a controversial claim does not advance his case.

\footnotetext{
${ }^{14}$ Räsänen, op cit. note 6, p. 629.

${ }^{15}$ Räsänen, J. (2017). Ectogenesis, abortion and a right to the death of the foetus. Bioethics 31(9), 697-702.

${ }^{16}$ Blackshaw, B.P, \& Rodger, D. (2018). Ectogenesis and the case against the right to the death of the foetus. Bioethics 33(1), 76-81.
} 
To address such speculative arguments, we will consider a more general question. If we grant the pro-life view that an infant has the right to life that a child or adult possesses, under what, if any circumstances may their right to life be overridden or forfeited? According to Maurice Cranston, human rights are of 'paramount importance' and 'something of which no-one may be deprived without a grave injustice ${ }^{17}$ : they take priority over other considerations such as government objectives or corporate interests. An important question is whether certain human rights are absolute - if the right to life is an absolute right, and in no circumstances can be overridden, then clearly, if infants are granted the right to life, infanticide is impermissible and Räsänen's argument fails.

Let us grant the more common non-absolutist position - that the right to life is prima facie, meaning that there are certain situations where trade-offs might be permissible — and examine how these trade-offs could occur. There are two possibilities: conflict with other human rights, and sufficiently bad circumstances that justify overriding rights. As the right to life is generally regarded as one of the most fundamental and important rights, being required to enjoy all other rights, it will trump other rights that conflict with it. For this reason, Räsänen's specific claim that genetic privacy might outweigh an infant's right to life cannot succeed.

What about circumstances that might justify overriding rights? The degree of badness required will depend on how strong a view one holds on human rights. For example, Robert

\footnotetext{
${ }^{17}$ Cranston, M. (1967). Human Rights, Real and Supposed. In D. D. Raphael (ed). Political Theory and the Rights of Man. London: Macmillan. p. 170-171.
} 
Nozick's view is that only a catastrophe such as a nuclear holocaust can outweigh a human right $^{18}$. Once again, under such a view it seems inconceivable that infanticide can be justified.

If we take a weaker view of rights, how can we judge what circumstances are required to override a right to life? One way of getting to grips with this is to examine the range of situations where it is accepted that the right to life can be overridden for adults. Self-defence is one of these: provided our response to an attack on our person is necessary and proportionate to the threat ${ }^{19}$, an attacker may be killed - even if they are an involuntary threat. The premise of self-defence can be extended to killing in just wars, and this might involve the unintentional killing of innocents who are unavoidably killed, as well as the risk to life of conscripted soldiers required to participate. Capital punishment, while controversial, is another widely accepted justification for overriding a person's right to life, provided the crime is of a very serious nature and a competent court process is followed. Finally, voluntary euthanasia, while again controversial, is permitted in numerous countries.

The circumstances listed above are exhaustive; we are not aware of any other justifications for overriding an adult human being's right to life ${ }^{20}$. The difficulty for Räsänen's position is clear: none of these justifications is even remotely applicable to deliberate infanticide. If an infant is granted a right to life, infanticide is impermissible, contrary to Räsänen's claim that

\footnotetext{
${ }^{18}$ Nozick, R. (1974). Anarchy, State, and Utopia. Basic Books, p. 30.

19 See Greasley, K. (2017). Arguments About Abortion: Personhood, Morality, and Law. Oxford: Oxford University Press, p. 59-60.

${ }^{20}$ Presumably a utilitarian might be willing to grant some human rights including the right to life as a useful fiction that increases utility, but this would entail granting these (fictional) rights to be of a similar strength to that assumed by non-utilitarians. If rights were weak enough that we could sacrifice one person for their organs in order to save several, they are arguably not 'rights' at all.
} 
'the premise that infants have a right to life does not by itself solve the question whether infanticide is immoral' ${ }^{21}$.

\section{Conclusion}

We appreciate the opportunity to exchange views with Räsänen, and have found his criticisms regarding the pro-life position to be valuable, even though we disagree with his conclusions. We have noted that even if Räsänen's substance view critique can be sustained (which we do not concede), there are numerous other views that can ground a pro-life position on the immorality of infanticide. We have shown that if an infant possesses a right to life, as maintained by pro-life advocates, infanticide is clearly impermissible - there are no conceivable circumstances where overriding its right to life can be justified. Accordingly, Räsänen's claim that pro-life arguments cannot show infanticide to be immoral fails.

${ }^{21}$ Räsänen, op cit. note 6, p. 629. 